\title{
Chapter 3 \\ Pasture growth limitations in hill country and choice of species
}

\author{
D.F. Chapman and M.J. Macfarlane \\ Grasslands Division, DSIR, Palmerston North \\ Whatawhata Research Station, MAF, Hamilton.
}

\section{INTRODUCTION}

There is undoubted potential for large increases in farm production from steep hill country. Estimates suggest stock numbers could more than doubie through both land development and intensification of current enterprises to top farmer levels. Many factors, economic, physical and social, influence current output, land development and intensification. Our intention is to review the physical and biological limitations to pasture production. These are of considerable concern to the farmer. In a recent survey, winter-early spring and summer feed shortages were the first and third most important reasons nominated by farmers for not carrying more stock.

We consider the main limitations to pasture growth in steep hill country are soil moisture, temperature, soil fertility and grazing management, not in any particular order of importance. Other factors, such as pests, diseases, weeds and waterlogging may be significant in certain areas or on particular farms but they will not be discussed here (see Chapters 7 and 9). For each limiting factor we suggest plant characteristics which can overcome, or help reduce the effects of the limitation. This leads to recommendations of species and cultivars for various situations. However, few evaluations have demonstrated increases in pasture production after oversowing new species and cultivars, and in many situations encouraging resident pasture growth by fertiliser application or altering stocking rate may be a more effective way of increasing farm productivity. Species introduction should be viewed as a complement to these procedures, not as a replacement for them.

\section{VARIABILITY DUE TO SLOPE, ASPECT AND MICROTOPOGRAPHY}

Hill country farms, or even individual paddocks, are not uniform. They are mixtures of steep and flat areas, stock tracks and banks, and of different aspects. These differences influence pasture growth. For example, stock camps in moist areas pose few limitations to pasture growth and produce 20-25 tonnes DM/ha/yr, equal to maximum lowland yields. However, steep dry faces may produce less than 5 tonnes $\mathrm{DM} / \mathrm{ha} / \mathrm{yr}$, usually of poor nutritive quality. Because different limiting factors operate in different areas, sunny and shady faces should ideally be fenced and managed separately. This is not always practical, especially in very broken land, but where it is possible different species and cultivars are best suited to different aspects (see Recommendations, below). Thus variability due to slope, aspect and microtopography within a farm should influence decisions about plant introduction, and points to the need for a broad genetic base of plants in the pasture. Seed mixtures for hill country should include several species, each of which may be suited to a particular niche within a large area, but not the whole area.

\section{CLIMATIC LIMITATIONS}

\section{Moisture}

Many regions of the North Island are regularly affected by summer-autumn moisture deficits. These include the drought-prone East Coast and parts of Northland, Waikato, Bay of Plenty, the Volcanic Plateau and Wanganui. Also, areas within regions generally considered summer-moist or wet can experience regular, localised moisture stress, e.g. steep, north faces.

In these areas, the legume component of pastures is dominated by annuals, with generally a low content of perennials such as white clover. Annuals emerge as seedlings in autumn as moisture levels increase, grow mainly during early spring then set seed and die during late spring-early summer. They therefore avoid moisture stress by existing as dormant seeds, impervious to moisture loss. Perennial plants remain vegetative as moisture deficits develop, and the resulting moisture stress kills many individuals. Recovery of perennial pasture 
Table 3.1 White clover stolon mass (kg DM/ha) at a Wairarapa hill site following the severe drought of 1983

\begin{tabular}{ccccccc}
\hline December 1982 & March 1983 & June 1983 & Sample date & September 1983 & December 1983 & March 1984 \\
\hline 282 & 84 & 26 & 42 & 139 & 308 \\
\hline
\end{tabular}

species from severe drought in North Island dry hill country may take a long time (Table 3.1).

Perennial species can survive drought in various ways e.g. through the development of semi-annual behaviour with early flowering and prolific seed production, the production of deep tap roots or the possession of special physiological or root morphological characteristics. Species possessing these features are not necessarily recommended for hill country. However, this species and individua within-species variation in the ability to tolerate soil moisture deficits will provide the basis for breeding plants better suited to dry hill country.

\section{Temperature}

Temperature plays a major role in controlling plant growth. Plant species have different temperature requirements; for instance, minimum temperatures for white clover and ryegrass growth in southern North Island hill country are about $9^{\circ} \mathrm{C}$ and $6-7^{\circ} \mathrm{C}$ respectively. While these differences appear small, they can mean several weeks difference in periods of active growth.

Temperature, like moisture, is a limitation in hill country which we cannot directly alter. However, sunny aspects generally have higher soil temperatures than shady aspects during winter and early spring, and this may suit some species or cultivars better than others. For example,, species of Mediterranean origin or content have greater cool season activity than temperate species and can respond better to higher winter or spring temperatures e.g. Pitau vs Huia white clover. This characteristic is of particular importance in legumes because of their greater sensitivity to cold,

Some New Zealand cultivars have been developed from plants growing in warm regions e.g. Nui and Ellett ryegrasses. Nui performs much better than Ruanui ryegrass on sunny aspects in hill country. In fact ryegrass has the best winter growth of all common grass species and will improve pasture production during critical late winter-early spring months. Any species sown on sunny aspects to exploit higher winter or spring temperatures must also tolerate low soil moisture levels in summer; Nui is a good example of a cultivar which fits both requirements.

\section{SOIL FERTILITY}

Nitrogen $(\mathrm{N})$ deficiency is the principal nutrient limitation to pasture growth in most hill country regions. Legumes fix $\mathrm{N}$ from the atmosphere, and transfer it to grasses through herbage death and decay, or through animal excreta. This is the key role of legumes in hill country. Most hill soils are inherently low in phosphate $(\mathrm{P})$, and this deficiency must be corrected for good clover growth, and consequently high $\mathrm{N}$ fixation, to occur. The effects of superphosphate on legume and grass growth in hill country are clearly illustrated in Fig. 3.1. Consistent increases in grass production lagged 2 years behind increases in clover production, but grasses continued to increase as clover production declined, probably as a result of increased competition from grasses. Higher levels of ryegrass resulted from improved $\mathrm{N}$ status of soils, and this increased winter growth rates (Fig. 3.1); thus elimination of one limiting factor can help alleviate other limitations. In the Ballantrae experiment, stocking rates reached 12.0 and 16.1 ewes/ha for low and high fertiliser treatments respectively in 1981, (initial stocking rate $=6$ ewes/ha), and were mainly governed by winter pasture growth rates. This is an example of a management procedure having a large influence on farm productivity, and of the value of encouraging desirable resident plants (in this case ryegrass, via the legume). White clover was oversown at the beginning of this experiment and probably accelerated the build up of soil fertility. Again, this is an example of species introduction complementing other management procedures rather than substituting for them.

\section{LIMITATIONS IMPOSED BY GRAZING MANAGEMENT}

There are two extremes of grazing management which limit pasture production (1) under-grazing (lax grazing pressure) which allows dead material to accumulate, shades out white clover and reduces pasture density and (2) over-grazing (severe grazing pressure) which also reduces pasture density and exposes bare areas for weed invasion. Between these extremes (represented by about 2.5-3.0 and 0.8-1.0 tonnes $\mathrm{DM} /$ ha herbage mass respectively), sheep management systems have relatively minor effects on pasture or animal production. Thus 'correct' grazing pressure is the key management requirement for good pasture production in hill country, and this is achieved through subdivision and manipulation of 


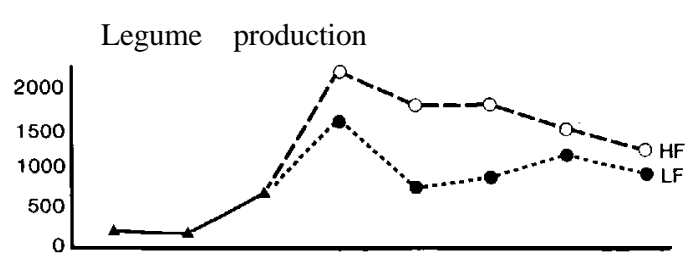

Grass production

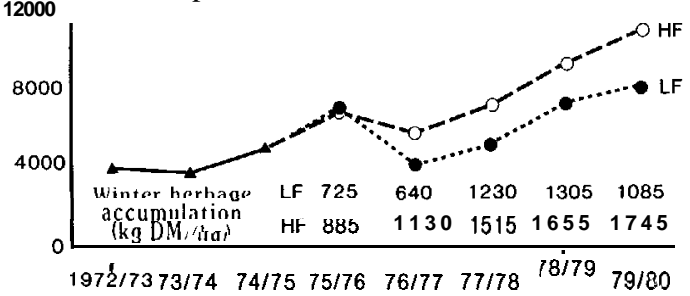

Figure 3.1 Legume and grass production $(\mathrm{kg} \mathrm{DM} / \mathrm{ha} / \mathrm{yr})$ in Ballantrae grazing trial during $1972 / 73 \quad 1979 / 80$. Low fertiliser $(\mathrm{LF}=11 \mathrm{~kg} \mathrm{P} / \mathrm{ha} / \mathrm{yr})$ and high fertiliser $(\mathrm{HF}=$ $57 \mathrm{~kg} \mathrm{P} / \mathrm{ha} / \mathrm{yr}$ ) treatments commenced in $1975 / 76$. Total winter herbage accumulation at each level indicated along $x$-axis. (From Lambert $\boldsymbol{e t}$ al. 1982. Proceedings of the New Zealand Grassland Association 43, 205-214 and Lambert et al. 1983. New Zealand Journal of Agricultural Research 26, 95-108)

\section{stocking rate}

Most hill country farms are extensively grazed compared to lowland farms with set-stocking the most common management. Controlled grazing systems, incorporating virtually year-round rotational grazing, are becoming more important. Under either system, frequent grazing close to ground level is normal. This damages erect plants with elevated crowns or apices, such as red clover and lucerne, which require special management to persist. This degree of management refinement is unlikely to be practical in hill country. Annual species should not be grazed severely in spring when producing seed, as flowers and seed can be removed by stock.

Large-leaved, freely stoloniferous or erect plants which bear their flowers high up in the pasture canopy are most at risk e.g. subterranean clover cultivars Clare and Woogenellup. In well utilised, intensively grazed swards, a prostrate, dense, medium-small leaved growth habit is desirable for persistence and production. Crowns or meristems should be at or below the soil surface to avoid frequent removal by stock.

Livestock species other than sheep are now widely farmed in hill country e.g. goats. These usually have very different defoliation patterns which can substantially change pasture composition. Their grazing patterns are generally complementary to those of sheep, offering new options for pasture management. For example, goats generally avoid grazing white clover, resulting in higher clover contents in the pasture which could be used to improve ewe nutrition at important times such as flushing, or for improving lamb growth rates. Higher production of meat and fibre is likely from mixed grazing than from either sheep or goats alone, particularly where weed species acceptable to goats but not to sheep occur.

\section{SPECIES CHOICE}

We concentrate on species for pasture renovation, for example after drought, erosion or treading damage, and pasture improvement. Species recommended for pasture improvement will also be important during development phases and should form the basis of mixes applied to newly cleared land.

Few species or cultivars can be recommended with confidence for hill country because:

1. only one cultivar, Tahora white clover, has been bred for, and selected in, hill country. Most others are intolerant of the close continuous defoliation and/or low fertility typical of hill country, e.g. red clover, prairie grass

2. many are slow to establish from oversowing and require high inputs (= high costs) for successful establishment, e.g. phalaris, tall fescue and

3. agronomic evaluations have been inadequate to define the value of most new cultivars. The likely roles of some suitable species and cultivars in relation to soil moisture and fertility gradients are outlined in Fig. 3.2.

For pasture renovation, white clover and ryegrass will establish rapidly and minimise weed invasion. Species such as suckling clover, crested dogstail, sweet vernal and browntop will invade sooner or later and need not be sown even if desired.

For pasture improvement, species choice is determined by the existing level of improvement:

1. if little fertiliser has been applied previously and pastures are weedy and poorly utilised, that is if pastures are essentially unimproved, introduction of 'improved' plants is unlikely to be advantageous. The exception in moist and wet areas might be lotus which is tolerant of low soil fertility and extensive grazing management, but is unproductive under intensive grazing

2. if moderate amounts of superphosphate have been applied, white clover is evident in pastures, and stocking rate and utilisation are average or better than average, that is if pastures are moderately improved, then oversowing legumes could be advantageous. Several cultivars should be used in mixture, and white clover should always be included 
SOIL

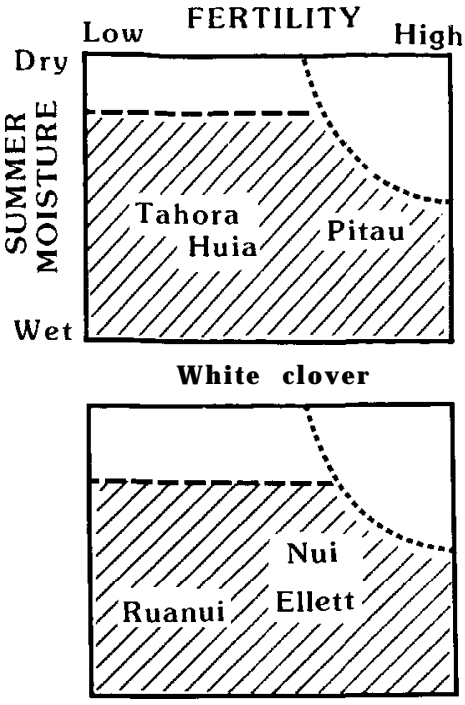

Perennial ryegrass

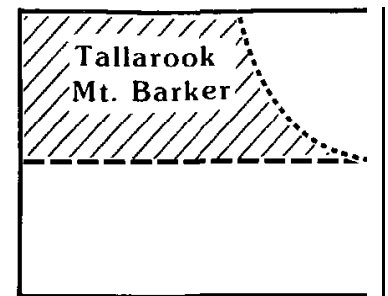

Subterranean clover

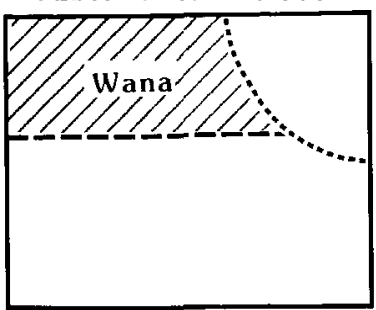

Cocksfoot

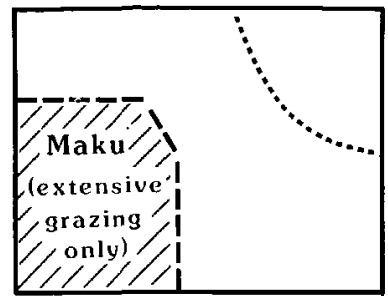

Lotus

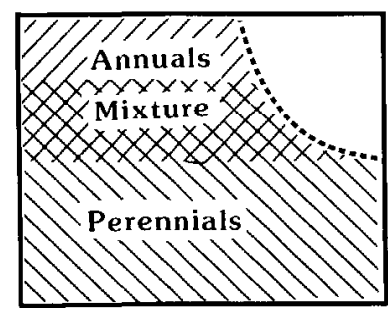

Figure 3.2 Fitness of legume and grass cultivars for North Island steep hill country environments created by variable soil fertility and summer moisture. The top right hand corner of each diagram (delineated by dotted curve) represents an environment (regularly summer dry, high fertility) probably unobtainable in hill country. The bottom right diagram is a generalised guide to composition of seed mixes for oversowing hill country and is mos? applicable to legumes where a range of suitable annual and perennial cultivars exists.

3. if fertiliser inputs, stocking rate and pasture utilisation have been high, pastures do not show early spring $\mathrm{N}$ deficiency (e.g. urine patches in yellow pasture), and ryegrass is distributed throughout, that is if pastures are highly improved, then grass as well as legume oversowing may be advantageous. The best choices here are ryegrass and cocksfoot.

\section{RECOMMENDATIONS}

We recommend use of the following species and cultivars in steep hill country:

1. 'White clover (perennial) should be the main legume sown in summer-moist or wet areas, except on dry faces where a white/sub clover mix would be more suitable. White clover should still be sown in summer-dry areas, as a minor component.

Cultivars: Tahora should replace Huia in all summer-moist or wet areas of lowmoderate fertility under sheep grazing.

Huia is recommended on moderate-high fertility sites under cattle grazing.

Pitau is not recommended except in high fertility, cattle-grazed swards in the northern North Island.

2. Subterranean clover (annual) should be the main legume for summer-dry regions, and only a minor component in moist or wet regions, except on dry faces (see above).
Cultivars: Tallarook produces well and persists in a wide range of environments.

Mt. Barker is similar to Tallarook.

Other listed sub clover cultivars, Woogenellup and Clare, are not persistent under intensive sheep grazing. The current unavailability of Tallarook seed means Mt. Barker is required to perform in all environments. More genetic variation is required in this species and quality seed supplies must be made available.

3. Perennial ryegrass is most valuable in moderately-dry, moist and wet environments.

Cultivars: Ruanui is best on shady aspects (where it outyields Nui) and is the most appropriate ryegrass cultivar for lowmoderate fertility.

$N u i$ is superior to Ruanui on sunny aspects. It is better adapted to moderatehigh fertility, and will respond to $\mathrm{N}$ fertiliser better than Ruanui. Where sunny and shady aspects cannot be sown separately, use a Ruanui/Nui mix, with the proportion of each cultivar dependent on existing level of fertility. Ellett should perform similarly to Nui.

4. Cocksfoot (perennial) is most useful in dry environments.

Cultivar: Wana has best morphology for hill country and is tolerant of low soil fertility. 


\section{SUMMARY}

1. The nost important factors limiting pasture growth in. North Island steep hill country are soil moisture deficits, winter early spring temperatures, soil fertilty and grazing management. The effects of these limitations can be reduced by appiopriate species choice and sowing techniques.

2. There are also management procedures which can overcome some of these limitations vers effectively by encouraging the growth of desirable resident species. Plant introduction should be used as a complement to good management procedures, not as a replacement for them, and should be accompanied by high uttisation of sown swards.

3. Only one cultivar currently on the New Zealand Acceptable Herbage Cultivars list has been bred for, and selected in. hill country. The others are not necessarily suited to hill country and nay not outyeld the resident plant population which is usually better adapted to the environment

4. A broad nixure of reconmended species and cultivars should be used when over sowing to exploit variation in slope, aspect and microtopography (and hence variation in limiting factors) which is a strong feature of hill country.

\section{FURTHER READING}

Levy E.B. 1970. Grasslands of New Zealand. 3rd Edition. Government Printer, Wellington.

Suckling F.E.T. 1965. Hill pasiture improvement. DSIR/Newton King Group.

White J.G.H. 1973. Improvement of hill country pastures. In: Langer R.H.M., editor. Pastures and pasture plants. A.H. \& A.W. Reed, Wellington. 